\title{
Wpływ religii i tradycji na konflikt na Molukach w latach 1999-2002
}

\section{The influence of religion and tradition on conflict in Maluku Islands in 1999-2002}

\author{
Simona Sienkiewicz \\ INSTYTUT BLISKIEGO I DALEKIEGO WSCHODU, UNIWERSYTET JAGIELLOŃSKI \\ UL. GRONOSTAJOWA 3, 30-001 KRAKÓW \\ simona.sienkiewicz@student.uj.edu.pl
}

\begin{abstract}
Niniejszy artykuł dotyczy wpływu religii i tradycji na konflikt, który miał miejsce na indonezyjskich Molukach w latach 1999-2002. Silne wpływy Holendrów w okresie kolonialnym sprawiły, że na wyspach utrzymała się chrześcijańska większość, co stanowiło wyjątek w zdominowanym przez muzułmanów państwie. Moluki wydawały się idealnym przykładem obszaru, gdzie panuje tolerancja i dialog między różnymi wyznaniami, aż do wybuchu konfliktu etnoreligijnego na przełomie XX i XXI wieku. W artykule zostanie omówiona geneza starć między muzułmanami a chrześcijanami oraz wykorzystanie zapomnianego prawa zwyczajowego i religii do procesu pokojowego.
\end{abstract}

This paper presents the influence of religion and tradition on conflict in Maluku, Indonesia. Thanks to the strong influence of the Dutch the province remains exception with Christian majority in country dominated by Muslims. Maluku seemed to be a perfect example of religious tolerance, however, it changed between 1999 and 2002 when the inhabitants experienced consequences of sectarian conflict. The reasons of this clash remain unclear and it was a blow to the national motto ,unity in diversity”. This article will discuss an attitude of people in Maluku who have used forsaken traditional laws and religion to reconciliation after conflict and have shown an interesting example of coexistence Christians, Muslims and followers of syncretic faiths. 


\section{Wprowadzenie}

Indonezję zamieszkuje obecnie około $250 \mathrm{mln}$ ludzi, a wśród nich dominują muzułmanie. Mieszkańców wysp Archipelagu Malajskiego charakteryzuje mozaika etniczna i językowa - przeszło 600 grup etnicznych (Ananta 2015: 83), 700 języków i niezliczonych, wciąż niezbadanych dialektów (Martí 2005: 48). Bez wątpienia ma to istotny wpływ na kształtowanie się synkretyzmu religijnego. Pojęcie synkretyzmu religijnego rozumiane jest jako łączenie religijnych wierzeń i praktyk w taki sposób, że ich pierwotne pochodzenie ulega zatarciu (Bowker 1997: 936). Praktykowanie tradycji przodków są bardzo silnie zakorzenione w indonezyjskim społeczeństwie, mimo obowiązujących oficjalnie $\mathrm{w}$ kraju sześciu religii - islamu, katolicyzmu, protestantyzmu, buddyzmu, konfucjanizmu i hinduizmu (Rudnyckyj 2013: 227). Obecnie zjawisko to jest szczególnie widoczne we wschodniej Indonezji, gdzie zróżnicowanie etnoreligijne ludności zalicza się do największych w państwie. Tamtejsi mieszkańcy wyznają niespotykane formy wyżej wymienionych religii, które wchłonęły do swoich rytów niektóre tradycje wywodzące się chociażby z animizmu. W omawianej w niniejszym artykule prowincji Moluki zjawisko to było szczególnie nasilone, a synkretyzm religijny odegrał istotną rolę w kształtowaniu się lokalnego prawa zwyczajowego, określanego mianem adat', oraz systemu pela ${ }^{2}$. Przez długi czas stanowiły one jedyną, nieoficjalną regulację w relacjach między muzułmanami a chrześcijanamis, którzy byli faworyzowani przez holenderską władzę kolonialną. Proklamowanie przez Indonezję niepodległości w 1945 r.4 przyniosło największe zmiany w mozaice religijnej Moluków. Spotęgowało je przybycie grup etnicznych i religijnych spoza prowincji w ramach polityki transmigrasis, usilnie

\footnotetext{
${ }^{1}$ Termin adat wywodzi się od arabskiego słowa 'âda 'zwyczaj' i zostało zaadaptowane w specyficznym znaczeniu w kulturze indonezyjskiej. Adat opiera się przede wszystkim na kultywowaniu tradycji praktykowanych przez przodków i był kluczowy przy przyjmowaniu nowych religii, które stopniowo adaptowały ich elementy. Przez wieki stanowił jedyne, umowne źródło pojmowania poprawnego zachowania i myślenia dla mieszkańców Moluków. Wyznaczał i wciąż wyznacza reguły dotyczące ceremonii religijnych, umów małżeńskich, sądzenia przestępstw, społecznych obowiązków czy rytuałów, które utrzymywały i utrzymują harmonię oraz porządek w społeczeństwie. Adat jest rodzajem prawa zwyczajowego, które silnie czerpało ze wspólnych tradycji wyznawców różnych religii wywodzących się z animizmu. W dużym stopniu przyczynił się do pokojowej koegzystencji islamu, chrześcijaństwa, hinduizmu, buddyzmu oraz konfucjanizmu wraz z lokalnymi wierzeniami w całej Indonezji. Zob. Forshee 2006: 37-43.

2 Pela był paktem łączącym chrześcijan i muzułmanów w wioskach, który miał zapobiegać międzywyznaniowym konfliktom. Zob. Bertrand 2004: 91.

3 Chodzi tutaj o nominalnych chrześcijan wyznania protestanckiego, którzy dominują na Molukach. Badając zagraniczną literaturę należy być ostrożnym, ponieważ w języku indonezyjskim kristen oznacza protestanta, co często mylnie tłumaczone jest na 'chrześcijaństwo'. Uwidacznia się to zwłaszcza w pracach angielskojęzycznych. Zob. Seo 2013: 17.

4 Mówiąc o niepodległości Indonezji, stosuje się trzy daty jej odzyskania. Wynika to z trwającej w latach 1945-1949 rewolucji niepodległościowej, a następnie przekształcenia federacji w republikę w 1950 r.

5 Transmigrasi (ind.) była polityką praktykowaną przez rząd indonezyjski, która zakładała przesiedlanie mieszkańców z gęsto zaludnionych terenów Jawy czy Sulawesi do mniej zamieszkałych prowincji. Więcej w: Hoey 2003.
} 
forsowanej przez Suharto ${ }^{6}$ Coraz bardziej napięta sytuacja w społeczeństwie szła $\mathrm{w}$ parze $\mathrm{z}$ rosnącymi problemami gospodarczymi i uprzywilejowaną pozycją chrześcijan wyznania protestanckiego, co okazało się wystarczającym impulsem do wybuchu konfliktu.

Artykuł ma charakter przeglądowy i przedstawi genezę konfliktu na Molukach w latach 1999-2002, ze szczególnym uwzględnieniem przebiegu walk na wyspie Ambon oraz rozwój islamu i chrześcijaństwa wraz z ich synkretycznymi odmianami w tamtym rejonie. Ma ukazać przyczyny zaangażowania się w krwawy konflikt przez społeczeństwo, które przed tymi wydarzeniami swobodnie rozwijało swoje życie duchowe i samodzielnie regulowało stosunki międzyreligijne. Podjęty temat jest niezbadany na gruncie polskiej indonezjanistyki, jak również europejskiej, gdzie rzadko porusza się kwestie Indonezji Wschodniej. Tymczasem omawiany problem jest wyjątkowy na tle przemian, które miały miejsce po upadku reżimu Suharto w 1998 r. W żadnej innej prowincji nie doszło do tak krwawego konfliktu, który byłby systematycznie podsycany przez różne grupy interesów.

W artykule celowo pomijam Moluki Północne, które od 1999 r. stanowią oddzielną prowincję Indonezji (Higgins 2009: 157). Zadecydowały o tym trzy czynniki. Po pierwsze, odmienna struktura etniczna i religijna Moluków Północnych, ze zdecydowanie dominującym islamem. Po drugie, konflikt na Molukach Północnych miał inne przyczyny, co było uwarunkowane odmienną historią i strukturą społeczną. Po trzecie, uwzględnienie Moluków Północnych wymagałoby przeprowadzenia obszernej analizy porównawczej, zasługującej na osobne, obszerne opracowanie.

Artykuł jest podzielony na cztery części. W pierwszej omawiam rozwój chrześcijaństwa oraz islamu, religii obecnie dominujących na Molukach. Ich źródła i sposób przyjęcia są istotne dla zrozumienia specyfiki społeczności, która adaptowała je według własnych przekonań tworząc niejako nowe, synkretyczne wierzenia. W drugiej części analizuję przyczyny wybuchu konfliktu, które tkwiły nie tylko w kwestiach etnicznych i religijnych, jak zwykło się je traktować, ale także gospodarczych i militarnych. W części trzeciej przedstawiam przebieg konfliktu oraz punkty zwrotne, szczególnie przybycie Laskar Jihad i eskalację walk za sprawą tego ugrupowania. W części czwartej omawiam działania pokojowe po konflikcie i oddolne inicjatywy, które znacząco przyczyniły się do odrodzenia synkretyzmu religijnego oraz prawa zwyczajowego.

\footnotetext{
${ }^{6}$ Suharto (1921-2008) był prezydentem Indonezji w latach 1967-1998 oraz twórcą Orde Baru (Nowego Ładu), który w polityce wewnętrznej opierał się na ożywieniu gospodarki i budowaniu jedności narodowej, natomiast $\mathrm{w}$ polityce zagranicznej zachęcał do inwestycji i budował relacje z blokiem zachodnim. System ten na wiele lat zakonserwował scenę polityczną Indonezji, był źródłem nepotyzmu i korupcji oraz krwawych działań wobec Timoru Wschodniego i Papui Zachodniej. Więcej w: Bonczol, 2012.
} 


\section{Rozwój islamu i chrześcijaństwa na Molukach}

Islam przybył na terytoria Archipelagu Malajskiego prawdopodobnie wraz z muzułmańskimi kupcami z Półwyspu Arabskiego, Chin i Indii (Bräuchler 2014). Merle Calvin Ricklefs, wybitny historyk Indonezji, pisze, że pierwsze namacalne ślady islamu, w postaci grobów, pojawiły się już na początku XIII w. (Ricklefs 2001: 4). Natomiast pierwszej potwierdzonej konwersji dokonał $\mathrm{raja}^{7}$ Pasai na terytorium północnej Sumatry; datowana jest ona na koniec tego samego stulecia (Bräuchler 2010). Nowa religia, szczególnie na Jawie, od początku miała charakter synkretyczny i pozytywnie odnosiła się do tradycyjnych systemów, które stanowiły istotny aspekt tamtejszej tożsamości ${ }^{8}$. Islam jawił się jako bardziej egalitarny w stosunku do zakorzenionych wcześniej religii - nie posiada restrykcyjnego systemu kastowego jak w hinduizmie czy instytucji mnichów buddyjskich.

Jeżeli chodzi o Indonezję Wschodnią, konwertyci prawdopodobnie zmieniali wyznanie głównie ze względów ekonomicznych. Przejście na islam gwarantowało szerszy dostęp do dóbr materialnych przywożonych przez kupców z innych terytoriów (Bräuchler 2014). Jest to jednak tylko jedna $\mathrm{z}$ wielu teorii wyjaśniających pojawienie się islamu $\mathrm{w}$ tym regionie. Przykładowo na Molukach Północnych, zgodnie z lokalną mitologią, pierwszym miejscem, w którym odnotowano obecność islamu, była miejscowość Fora Madidi, gdzie arabski podróżnik, potomek Mahometa, Jafar Sadek, zakochał się i poślubił księżniczkę spoza świata ziemskiego Para miała czterech synów, którzy ustanowili analogiczną liczbę sułtanatów (Bubandt 2009). Wedle innej wersji islam przybył wraz $\mathrm{z}$ kupcem jawajskim, który przekonał władcę sułtanatu Ternate (położonego na Molukach Północnych) do przyjęcia religii muzułmańskiej pod koniec XV w. (Bräuchler 2014). Rozpowszechnianiu islamu sprzyjało poważanie w społeczeństwie, a osoby stojące na czele misji, mających na celu islamizację lokalnych społeczeństw, były nagradzane przez sułtanów wysokimi stanowiskami. Dzięki temu islam dotarł na terytorium obecnej prowincji Moluki, które przed kilkoma wiekami były pod wpływem bardziej znaczących Moluków Północnych9. Mieszkańców Ambon oraz archipelagu Lease (zwłaszcza wysp Haruku i Separua) skusiły do konwersji na islam korzyści, które z tego płynęły oraz alternatywa dla brutalnej odmiany animizmu, bazującego na kulcie łowców głów (Bräuchler 2014). Wraz z przyjęciem islamu najważniejszą osobą w wiosce zostawał raja, którego rola polegała na byciu bezpośrednim mediatorem między Bogiem a wyznawcami. Dzięki temu zyskiwał wyłączną kontrolę nad przekazem religii. Zmieniło się to dopiero w XIX i XX w., wraz ze wzrastającą liczbą indonezyjskich pielgrzymów odwiedzających Mekkę. W związku z coraz lepszą komunikacją i wymianą handlową przesłanie płynące z ruchów

\footnotetext{
7 Ind. 'władca'.

8 Przykładowo w islamizacji Jawy kluczową rolę odegrali tzw. wali songo 'dziewięciu świętych'. Ponadto istniało wiele innych różnic, w tym włączanie do rytu tradycji pochodzących z lokalnych kultur - z perspektywy Arabii nie czyniły indonezyjskiego islamu tym „prawdziwym”. Zob. Laskowska 2012: 29.

9 Moluki oddzieliły się od Moluków Północnych w 1999 r.
} 
powrotu do zasad „czystego islamu” dotknęło również Moluki. Większość wyznawców była zdziwiona, że islam nie jest otwarty na synkretyzm religijny tak, jak wcześniej myśleli. Niektóre obszary wciąż próbowały praktykować godzenie elementów animistycznych z islamem, jednak pojawiało się coraz więcej rozłamów, często w obrębie jednej wioski. Szczytowym momentem w ruchu „powrotu do korzeni” było przybycie na Moluki ruchu Muhammadiyah ${ }^{10} \mathrm{z}$ Jawy na początku lat 30. XX w. Reformatorzy chcieli przeformułować prawo lokalne w taki sposób, żeby było interpretowane zgodnie z szariatem.

Decydujący wpływ na pozycję muzułmanów na Molukach miało przybycie katolickich Portugalczyków w 1512 r. (Bartels 1979), a następnie protestanckich Holendrów. Zachwiało to dotychczasową strukturą religijną, w której dominował islam oraz wyznania animistyczne. Portugalska wizja chrystianizacji Wysp Korzennych - jak się mówi o Molukach - zakładała, że ich mieszkańcy są poganami, co wiązało się m.in. z koniecznością przyjęcia chrztu oraz przystąpieniem do pozostałych sakramentów (Andaya 1993: 198). Wraz z rosnącą liczbą nawróceń w społeczeństwie dochodziły do głosu dylematy moralne, które dotyczyły włączania animistycznych tradycji do nowoprzyjętego obrządku. Jednak nie trwało to długo, ponieważ dominacja Portugalczyków została zakończona po niecałym wieku przez Holendrów. Dopłynęli oni na Wyspy Korzenne w 1605 r. i do 1799 r. zarządzali Molukami jako Holenderska Kompania Wschodnioindyjska (Vereenigde Oostindische Compagnie - VOC), która była zainteresowana przede wszystkim powiększaniem swojego majątku, a nie rozwojem duchowym mieszkańców. Jednak z czasem kupcy zaczęli traktować mieszkańców Moluków jako lud podbity i wprowadzili zasadę cuius regio eius religio ${ }^{11}$ zmuszając katolików do przejścia na protestantyzm, a następnie zlikwidowali ustanowione przez Portugalczyków misje religijne (Bräuchler 2014). Pod koniec XVIII w. VOC została oficjalnie zastąpiona przez holenderski rząd kolonialny, który z dużą gorliwością rozpoczął krzewienie wyznawanej przez siebie religii. Dostrzeżono jej „potencjał”, ponieważ religię protestancką zaczęto używać jako narzędzie kontroli nastrojów ludności. Mianowicie konwertyci zyskiwali duże wpływy w lokalnych społecznościach wspierając Holendrów poprzez oddolne inicjatywy. Problemem pozostawał brak profesjonalnych misjonarzy oraz samozwańczy duchowni, którzy czuli się powołani przez Boga do nawracania niewiernych. Stanowili duże zagrożenie dla rozwoju harmonijnego synkretyzmu religijnego, ponieważ byli fanatykami religijnymi i promowali radykalną wersję chrześcijaństwa z wyraźnym nastawieniem przeciwko zakorzenionemu $\mathrm{w}$ tradycji prawu adat i systemowi pela.

Chrześcijan wyznania protestanckiego szczególnie faworyzowano w Ambon. Stolica prowincji była jednym $\mathrm{z}$ najważniejszych miast

\footnotetext{
${ }^{10}$ Muhammadiyah jest organizacją sunnicką, została założona w 1912 r. w Yogyakarcie przez Ahmada Dahlana, a jednym z jej głównych celów było propagowanie islamu w jego pierwotnej formie. Więcej w: Fuad 2002.

11 Łac. 'czyj kraj, tego religia'.
} 
Holenderskich Indii Wschodnich ze względu na strategiczne położenie handlowe. W związku z tym zapotrzebowanie na urzędników było tak duże, że Holendrzy nie byli w stanie obsadzać stanowisk wyłącznie Europejczykami. W zamian za przejście na protestantyzm oferowano miejscowym ważne stanowiska zarządcze. Ignorowano przy tym muzułmanów, którzy migrowali na wieś, nie chcąc doświadczać dyskryminacji ze względów religijnych. Kolonizatorzy długo nie mogli się zdecydować, co zrobić z katolikami, których obecność była efektem pobytu Portugalczyków na Molukach. Ostatecznie, od 1865 do 1935 r. byli zmuszani do przejścia na protestantyzm (Bertrand 2004). Jednak kalwinistyczne, surowe podejście nigdy nie zadomowiło się wśród konwertytów z Ambon, którzy w praktyce nie realizowali bardziej radykalnych aspektów, jak np.: predestynacja czy pokuta z powodu współżycia seksualnego, spożywanie alkoholu, uprawianie hazardu itd. (Bartels 2003). Zmiana religii była w dużej mierze symboliczna i wykorzystywano ją do celów politycznych.

W latach 1816-1817 wybuchła rebelia przeciwko kolonizatorom, zwana powstaniem Pattimury'12, gdzie ramię $\mathrm{w}$ ramię walczyli muzułmanie i chrześcijanie. Została ona brutalnie stłumiona i od tamtej pory wyznawcy islamu zostali ostatecznie zmarginalizowani. Od połowy XIX w. do końca panowania holenderskiego chrześcijanie dominowali na każdym polu, od administracji po handel. Sytuacja zmieniła się dopiero w trakcie II wojny światowej, wraz z przybyciem Japończyków, którzy zaczęli na nowo układać stosunki z muzułmanami. Po pełnym uzyskaniu niepodległości w 1949 r. Holendrzy wraz z ambońskimi oficerami podjęli ostatnią próbę utrzymania wpływów w regionie, wspierając separatystyczne plany miejscowych wojskowych. Utworzono Republikę Południowych Moluków (Republik Maluku Selatan), która miała być autonomicznym obszarem, wyłączonym z Indonezji (Bartels 2003). Mimo że inicjatywa upadła po kilkumiesięcznych walkach, zaznaczyła się głęboką rysą w relacjach między chrześcijanami a muzułmanami. Rząd w Dżakarcie zdecydowanie dążył do ujednolicenia indonezyjskiej mozaiki religijnej w celu zmniejszenia ryzyka rozdrobienia ogromnego państwa. W tym celu jako język urzędowy wybrano indonezyjski oraz wprowadzono wąski zakres oficjalnie obowiązujących religii, co szczególnie mocno egzekwowano od końca lat 60. Obywatele do dzisiaj mają ograniczony wybór między islamem, katolicyzmem, protestantyzmem, buddyzmem, hinduizmem oraz konfucjanizmem. Ostatecznie, mimo wysiłków chrystianizacyjnych Holendrów, niemal 90\% Indonezyjczyków deklaruje się jako muzułmanie. Pod tym względem wyjątkiem pozostały Moluki, gdzie do dzisiaj chrześcijaństwo ma podobną liczbę wyznawców, co islam ${ }^{13}$.

12 Pattimura to Thomas Matulessy, który przewodził powstaniu przeciwko Holendrom w latach 18161817. Zdradzony przez lokalnego króla, został powieszony w 1817 r. Więcej w: Leirissa 1995.

13 Zob. dane pochodzące z bazy Badan Pusat Statistik, będącej wiodącym ośrodkiem badań statystycznych w Indonezji. 


\section{Przyczyny wybuchu konfliktu muzułmańsko- chrześcijańskiego}

Przyczyny wybuchu konfliktu, który miał miejsce w latach 1999-2002, tkwiły głęboko w czasach kolonialnych. Holenderskie władze dbały o zachowanie dystansu pomiędzy chrześcijanami a muzułmanami i systematycznie umacniały pozycję tych pierwszych, co skutkowało licznymi nadużyciami. Konwertyci mieli lepszy dostęp do edukacji oraz możliwość uzyskania wpływowych stanowisk w biurze gubernatora. Ambon było miejscem, gdzie religia stanowiła element politycznej gry, łączącej się ze zdobyciem oraz utrzymaniem wysokiej pozycji w społeczeństwie (Jeroen 2010). Sytuacja trwała w takim kształcie do lat 9o., a dopiero upadek reżimu Suharto drastycznie zmienił nastroje panujące wśród mieszkańców (Braithwaite, Duhn 2010: 181). Opozycja coraz mocniej krytykowała chrześcijan za rzekome wspieranie separatystycznych tendencji, odwołując się do próby utworzenia Republiki Południowych Moluków. Wraz z końcem Orde Baru władze zadecydowały o przekazaniu części kompetencji prowincjom, co miało przyczynić się do bardziej efektywnego funkcjonowania ogromnego państwa. Jednak pierwsze oznaki nadchodzących zmian pojawiły się już podczas kadencji pierwszego muzułmańskiego gubernatora Moluków, Akiba Latuconsina (1992-1998) (van Klinken 2007: 93), który zdecydował się umieścić współwyznawców na najważniejszych stanowiskach w lokalnej biurokracji. Wszyscy chrześcijańscy zarządcy bupati zostali zdegradowani z dotychczasowych stanowisk na rzecz muzułmanów, nawet w miejscach, gdzie stanowili większość (Bertrand 2004: 118). Cierpiały na tym niektóre sektory, m.in. zdrowia i edukacji, gdzie również przyjęto parytety religijne. Ponadto większość osób zatrudnionych na nowych zasadach pochodziła spoza Moluków, ze względu na brak odpowiednio wykształconych kandydatów w prowincji. Przed 1998 r. potencjalne źródła konfliktu były tłumione przez wojsko, ale zmiany zachodzące w Indonezji pozostawiły wiele aspektów otwartych do ponownej negocjacji (Bertrand 2008). Duże grupy etniczne i religijne dostrzegły $\mathrm{w}$ tej sytuacji okazję do uzyskania szerszych przywilejów i autonomii.

Rosnące napięcie między muzułmanami a chrześcijanami w Ambon było spowodowane również polityką transmigrasi, jednym $\mathrm{z}$ flagowych projektów Orde Baru. Oficjalnie wprowadzono ją ze względu na chęć zmniejszenia problemu przeludnienia innych wysp (szczególnie Jawy i południowego Sulawesi), ale najwięcej muzułmanów przesiedlono na w większości chrześcijańskie Moluki. Urzędnicy przyznawali, że w przypadku tej prowincji katolickie lub protestanckie wyznanie zazwyczaj skutecznie blokowało możliwość uczestnictwa w transmigrasi (Bertrand 2004: 121). Od 1969 do 1999 r. aż 25319 gospodarstw domowych, czyli 97 422 osoby przeniosły się na Moluki, głównie na wyspy Buru i Seram (Wilson 2008: 44). Muzułmanie z południowego Sulawesi w większości osiedlili się w Ambon. Kombinacja rywalizacji gospodarczej i różnic kulturowych 
doprowadziła do niechęci pomiędzy rodowitymi mieszkańcami Ambon a przybyszami wywodzącymi się z etnicznych grup Bugisów, Butonijczyków oraz Makassarczyków. Zdominowali oni sektory wymagające niewykwalifikowanej siły roboczej oraz usługi. Tymczasem kryzys azjatycki z 1997 r. zmusił chrześcijan do rywalizacji o pracę, którą wcześniej gwarantowała im wyznawana religia. Zatłoczone obszary $w$ stolicy prowincji, takie jak Batu Merah czy Mardika, przez cały czas doświadczały drobnych potyczek, szczególnie wśród młodzieży. Natomiast na wsiach negatywne napięcia skupiały się wokół prawa własności oraz kwestii kupna ziemi przez nowoprzybyłych, czemu sprzeciwiały się lokalne społeczności (Jeroen 2010). Znaczącą rolę wciąż odgrywał adat, który mimo prób wprowadzenia oficjalnego prawa wciąż utrzymywal swoją dominującą pozycję $\mathrm{w}$ moluckich społecznościach lokalnych. Tymczasem imigranci przedstawiali go jako narzędzie terroru etnicznego, który blokował dostęp do swobodnego rozwoju dla wszystkich mieszkańców.

Konflikt na Molukach spowodowany był pośrednio przez trzy czynniki, a mianowicie głęboko zakorzenione nieporozumienia społeczne, liderów dążących do realizacji własnych interesów poprzez wzmacnianie podziałów oraz niewydolność lokalnego systemu bezpieczeństwa (Braithwaite 2007: 38). Incydentalne zdarzenia poza Molukami również przyczyniły się do pogłębienia negatywnych nastrojów. Jedno z takich zajść miało miejsce w Dżakarcie, gdzie 22 listopada $1998 \mathrm{r}$. wybuchła sprzeczka na parkingu kasyna kontrolowanego przez chrześcijański gang z Ambon. Była to iskra, która wznieciła poważną kłótnię pomiędzy muzułmanami a chrześcijanami na Molukach. Następnego ranka gazety szeroko rozpisywały się o szkodach, które wyrządzili protestanci, m.in. o podpaleniu meczetu oraz pobiciach. Przypuszcza się, że kłótnia ta miała charakter prowokacji, jednak istnieje zbyt wiele nieścisłości, żeby stwierdzić to jednoznacznie. Efektem był odwet muzułmańskiego gangu z Ambon, który w zemście zniszczył i poważnie uszkodził 21 kościołów i kilka chrześcijańskich szkół (Wilson 2008: 43). W ciągu następnych dwóch miesięcy coraz częściej dochodziło do niewielkich starć między muzułmanami a chrześcijanami w Indonezji, np.: w Kupangu na Timorze Zachodnim oraz na Timorze Wschodnim. W grudniu 1998 r. wybuchł duży konflikt w Poso, położonym w Sulawesi Centralnym, który ostatecznie przyczynił się do wzrostu napięcia w całym państwie (Braithwaite 2010: 152). Niewielkie starcia nie ominęly Moluków, przykładowo 12 grudnia 1998 r. do potańcówki zorganizowanej przez chrześcijan w Hative Besar chciał dołączyć muzułmański żołnierz (Bertrand 2003: 124-125). Sytuacja przerodziła się $\mathrm{w}$ bójkę pomiędzy młodzieżą a wojskiem, której skutkiem było spalenie kilku domów. Nie było to jedyne zdarzenie tego typu, ponieważ muzułmanie często dawali wyraz dezaprobaty wobec chrześcijańskich imprez, na których tańczono oraz spożywano alkohol. Ukazywało to skrywaną przez lata nietolerancję, która długo szukała ujścia w większym konflikcie 


\section{Wybuch i przebieg konfliktu}

Jedne z pierwszych niepokojących zdarzeń na Molukach miały miejsce w maleńkim mieście Dobo, położonym na wysepkach Aru, kilkaset kilometrów na południowy wschód od Ambon (Braithwaite, Duhn 2010: 156). Natomiast w stolicy konflikt rozpoczął się 19 stycznia 1999 r., a punktem zapalnym okazała się kłótnia pomiędzy kierowcą autobusu miejscowym chrześcijaninem - a muzułmańskim pasażerem, z pochodzenia Bugisem z Sulawesi. Pierwsza faza konfliktu prawdopodobnie zabrała żniwo w postaci niemal 1000 ofiar śmiertelnych (Braithwaite, Duhn 2010: 157). Obie strony były do siebie bojowo nastawione i wyszły dogłębnie skrywane przez lata urazy, np.: pomiędzy byłymi wojskowymi, społecznościami kombatantów, którzy już wcześniej ze sobą rywalizowali, ale bez bezpośrednich ataków. Rozróżnienia stron dokonywano na podstawie stroju - muzułmanie nosili białe opaski a chrześcijanie czerwone. Część interpretowała to jako prowokację, ponieważ kolory te stanowią narodowe barwy Indonezji, a ich użycie w ten sposób negowało jedność, którą miały promować. Atak na symbole religijne oraz narodowe okazał się nośnym tematem, bowiem zamieszki szybko przeniosły się na inne miasta i wyspy na Molukach, takie jak: Aru, Arvis, Babar, Buru, Haruku, Kasuai, Kei, Manipa, Sanana, Separua, Seram, Tanimbar, Teor oraz Tual (Braithwaite, Duhn 2010: 157). Przemoc nie była skierowana przeciwko obcym czy okupantom, a walki toczyły się między sąsiadami, którzy pochodzili z tej samej dzielnicy lub wioski. W związku z tym konflikt był dosyć hermetyczny i niezrozumiały dla osób z zewnątrz, a różnica między ofiarami a sprawcami zacierała się. W szczytowej fazie walk rywalizujące ze sobą stronnictwa chciały przyciągnąć uwagę opinii publicznej w całym kraju (Jeroen 2010). Starano się publikować jak najwięcej zdjęć, filmów oraz płyt $\mathrm{z}$ amatorskimi nagraniami, które miały pokazywać wzajemne przewinienia i nasilały negatywne emocje. Muzułmanie szczególnie odwoływali się do kolaboracji chrześcijan $\mathrm{z}$ Holendrami i wspomnianego projektu Republiki Południowych Moluków, która według nich miała na celu masową i przymusową chrystianizację (Hasan 2005). Przemoc szybko eskalowała na całe społeczeństwo, które wykazywało agresywne nastawienie. W trakcie bójek używano wszelkiego rodzaju broni, od maczet, poprzez łuki, aż po ręcznie produkowane narzędzia zbrojne (Bhakti, Yanuarti, Nurhasim 2009). Incydenty polegające na paleniu sklepów oraz mieszkań przez obydwie strony doprowadziły do śmierci wielu osób i zniszczeń miast oraz wiosek. Mieszkańcy zaczęli poszukiwać bezpiecznego schronienia w kościołach, meczetach czy urzędach. Główne walki toczyły się między chrześcijańską dzielnicą Mardika a muzułmańską Batu Merah i uczestniczyli w nich przede wszystkim młodzi ludzie (Braithwaite, Duhn 2010: 157). Ambon podzieliło się wyłącznie na obszar chrześcijański (60\%) oraz muzułmański (40\%), a każda grupa miała swoją strefę wpływów. Największy meczet oraz kościół stały się głównymi centrami działań. Tymczasem policja i armia nie były odpowiednio przygotowane - zamiast 
łagodzić zamieszki, często je prowokowały (Goss 2000). Do stycznia 2000 r. wydawało się, że przewagę uzyskali chrześcijanie, jednak sytuacja zmieniła się diametralnie, gdy niemal 4000 bojowników Laskar Jihad przybyło z Jawy i Sulawesi, żeby bronić swojej religii (Braithwaite, Duhn 2010: 158). Głównym powodem mobilizacji tego ugrupowania były pogłoski o masakrze muzułmanów w meczetach na Molukach Północnych, gdzie nigdy nie dotarli. Wytrenowani przez wojskowych w Bogor pod Dżakartą ekstremiści, popłynęli na wschód mimo zakazu prezydenta Abdurrahmana Wahida. Siły te, wraz z przybyłym wcześniej niewielkim odłamem Laskar Mujahidin (Abuza 2007: 44), były powiązane z inicjatywą terrorystyczną w Indonezji, znaną jako Jimaah Islamiyah. Przywieziono broń maszynową oraz wyrzutnie rakiet, co przyczyniło się do eskalacji wygaszającego się konfliktu. Pod koniec 2000 r. blisko 1/3 mieszkańców Moluków została zmuszona do opuszczenia swoich domów, z których duża część została doszczętnie spalona. Pod koniec walk liczba uchodźców dochodziła nawet do połowy mieszkańców całej prowincji (Braithwaite, Duhn 2010: 158).

Mimo konfliktu miejscowa ludność na niektórych obszarach pozostała wierna tradycyjnym systemom gwarantującym bezkonfliktową koegzystencję. Kiedy w 1999 r. rozpoczęły się walki w małej wiosce Wayame, ludzie spotkali się w celu przedyskutowania sprawy, a konkretniej sposobów uniknięcia negatywnych konsekwencji sporu. Ustalono muzułmańskochrześcijańską straż nocną składającą się $\mathrm{z}$ dziesięciu osób każdego wyznania. Zabroniono sprzedaży alkoholu oraz broni, a wszelkie podejrzane sytuacje miały być zgłaszane patrolującym. Ważną rolę odegrały kobiety, które regularnie się spotykały w mieszanym religijnie środowisku i za cel obrały sobie utrzymanie interakcji oraz zaufania między obiema stronami. Ponadto dbały o dobrą wymianę handlową, przez co demonstrowały, że istotne są umiejętności człowieka, a nie jego wyznanie. Było to pokłosie systemu pela, który był tak silnie zakorzeniony w świadomości społecznej mieszkańców wsi, że sporo wiosek na takich wyspach jak Haruku, Separua czy Nusa Laut nie zaangażowało się czynnie w walki. Jednak relacje oparte na porozumieniu nie były wystarczające, żeby zapobiec eskalacji konfliktu przede wszystkim ze względu na duży udział imigrantów, którzy nie przestrzegali zasad tradycyjnych systemów. W tej sytuacji na całych Molukach 26 czerwca $2000 \mathrm{r}$. wprowadzono stan wyjątkowy, a rząd wysłał grupy specjalne do ustabilizowania sytuacji. Skuteczność wojska wzrosła wraz z wyborem nowej prezydent - Megawati Sukarnoputri, mającej nacjonalistyczne poglądy i blisko związanej ze środowiskiem wysokich oficerów. Dodatkowo czuła na sobie presję związaną z wydarzeniami z 11 września oraz zamachami terrorystycznymi na Bali (Goss 2000).

\section{Pokój i perspektywy dalszego dialogu międzyreligijnego}

Pakt pokojowy, zwany Malino II, został podpisany w lutym 2002 r. w miejscowości Malino na Sulawesi Południowym. Konflikt zmusił niemal pół miliona ludzi do ucieczki. W październiku 2003 r. indonezyjski rząd 
przeprowadził oficjalny spis, wedle którego oszacowano, że 70 tys. rodzin, czyli ponad 330 tys. mieszkańców zostało uchodźcami w wyniku walk. Natomiast 160 tys. wyjechało do innych prowincji, szczególnie na Sulawesi Południowe (Brown, Wilson, Hadi 2005: 38). Były to jednak głównie osoby, które osiedliły się wcześniej na Molukach w ramach polityki transmigrasi. Stan wyjątkowy w prowincji zniesiono dopiero w 2003 r. (Lowry, Littlejohn 2006). W późniejszych miesiącach odnotowywano sporadyczne incydenty, w szczególności na stołecznej wyspie Ambon. Przykładowo w 2004 r. wywieszono flagę Republiki Południowych Moluków na domu Alexa Manputty'ego, chrześcijańskiego przywódcy Ruchu Niezależności Moluków (Front Kedaulatan Maluku - FKM)14, a jego członkowie zostali oskarżeni o ataki snajperskie (Braithwaite, Duhn 2010: 160). Lokalni oficerowie chcieli wykorzystać jeszcze świeży konflikt do swoich interesów, bowiem zbrojne starcia przyniosłyby im profity finansowe oraz lepszą pozycję w wojsku. Ryzyko ponownych zamieszek w Ambon podniosła również repatriacja osób, które w czasie walk zostały zmuszone do uchodźstwa. Wiele $\mathrm{z}$ nich dostrzegło zmiany działające na ich niekorzyść oraz brak możliwości powrotu do swoich domów, które zostały zawłaszczone bądź zniszczone podczas ich nieobecności (Jeroen 2008).

Rola tradycji była bardzo istotna dla społeczeństwa powracającego do codziennego życia. Mieszkańcy musieli zmierzyć się z przeszłością, żeby dalej koegzystować, ponieważ zdarzały się sytuacje, gdzie krzywdy doświadczano od najbliższego środowiska. System pela pozostał i pozostaje jednym z głównych czynników regulujących pokojowe współistnienie zróżnicowanych religijnie wiosek na Molukach. Tymczasem adat jest wykorzystywany przez oficjalne służby przed przystąpieniem do stosowania oficjalnego, indonezyjskiego prawa. Konflikt wzmocnił powrót do źródeł, czyli rozwiązań, które oddolnie porządkowały życie wspólnot na Molukach. Po zakończeniu walk powstało wiele inicjatyw, które miały na celu zapobiec podobnym sytuacjom w przyszłości. Jedną z nich była Molucka Rada Międzyreligijna (Lembaga Antar Iman Maluku - LAIM), która powstała w grudniu 2003 r. i składała się z reprezentantów głównych religii w prowincji, czyli Moluckiego Kościoła Protestanckiego, Katolickiej Diecezji Ambońskiej oraz Rady Muzułmańskich Ulemów (Bräuchler 2014). Rada miała na celu podnosić świadomość podobieństw między religiami i nauczać o ich pozytywnych stronach. Stanowiła również forum dla religijnych przywódców, gdzie mogli się spotykać oraz dyskutować o ewentualnych napięciach i tłumieniu ich $\mathrm{w}$ zarodku. Ponadto angażowano się w różne akcje społeczne, mające na celu promowanie religijnej równości i dialogu. Natomiast pomoc międzynarodowa okazała niezbędna w kwestii uchodźców, których ogromna liczba przytłoczyła zarówno miejscowe, jak i narodowe władze. Organizacje pozarządowe zapewniały tymczasowe miejsca pobytu oraz dbały o bezpieczny powrót do odbudowywanych domów i mieszkań.

${ }^{14}$ Zob. treść porozumienia Malino II. 
Konflikt wpłynął na odrodzenie synkretyzmu religijnego, szczególnie na terenach wiejskich, gdzie wspólnie przygotowywano święta muzułmańskochrześcijańskie, jak Boże Narodzenie czy Idul Adha. Gdy zmarł chrześcijański lider - John Mylock, ogromna liczba muzułmanów nie tylko uczestniczyła w uroczystościach pogrzebowych, ale także wszystkie zajęcia na Institut Agama Islam Negeri Ambon rozpoczęły się minutą ciszy. Popularnym rytuałem stało się halal bi halal czyli proszenie o wybaczenie za złe traktowanie w przeszłości (Braithwaite, Duhn 2010: 177). W Dżakarcie prasa rozpisywała się, że są to powierzchowne i nieszczere zachowania, jednak dla mieszkańców Moluków zyskały one nowy wymiar. Ostatecznie obydwie strony były świadome, kto dopuszczał się podpaleń, dewastacji i zabójstw, ale mieszkańcy zdali sobie sprawę, że brak oddolnych inicjatyw może doprowadzić do kolejnych tragedii. Dlatego też od 2004 r. Moluki pozostają względnie spokojnym miejscem. Stopniowo likwidowano w Ambon strefy, które uniemożliwiały swobodne przemieszczanie się i były żywym dowodem niedawnych walk. Co prawda, w 2006 r. odnotowano dwie eksplozje bomb, cztery zaś w 2007 r. (Braithwaite, Duhn 2010: 160), ale $\mathrm{z}$ drugiej strony $\mathrm{w}$ tym samym czasie pierwszy Jawajczyk został skazany za terroryzm w stolicy prowincji, co pokazało brak tolerancji dla tego typu działań. Jednak rozwiązania zmierzające ku pokojowi nie były wszystkim na rękę - zatarg między policją a wojskiem wciąż pozostaje żywą kwestią w Ambon i każdego roku przynosi kilka ofiar śmiertelnych. W lutym 2008 r. wojsko zniszczyło dom szefa policji Moluków, a 56 pozostałych mieszkań służb tej jednostki zostało zdewastowanych. Innym razem dwóch policjantów oraz żołnierz zostali ranni w wyniku kłótni na tle obyczajowym - siostra żołnierza została przyłapana na akcie seksualnym z policjantem (Braithwaite, Duhn 2010: 160). W tej sytuacji dyskusyjny jest prawdziwy powód zamieszek, które miały miejsce od 1999 do 2002 r., jednak z pewnością dużą rolę odgrywała chęć zdobycia władzy i wzmocnienia swoich pozycji pod pretekstem niezgody na tle etnicznym i religijnym.

\section{Podsumowanie}

Moluki są dobrym przykładem, że nie wszystkie prowincje bezkrwawo przeszły upadek dyktatury Suharto. Konflikt ten pokazał, że rozległość Indonezji niekoniecznie jest jej atutem. Nowa administracja w odległej Dżakarcie skupiała się przede wszystkim na umacnianiu pozycji na Jawie i Sumatrze, przez co nie do końca rozumiała problemy mieszkańców z odległych prowincji. Potwierdza to stosunkowo długa reakcja władz na wydarzenia 1999 r. oraz brak pomysłu na szybkie rozwiązanie konfliktu. Atmosfera wcześniej przez długi czas była napięta, więc $\mathrm{z}$ pewnością na wyższych szczeblach zdawano sobie sprawę $\mathrm{z}$ zagrożenia. Sytuacja pogorszyła się, gdy bojownicy Laskar Jihad wymknęli się spod kontroli, co miało duże znaczenie przy rosnącym zagrożeniu terroryzmem w kraju i na świecie. Przez cały okres trwania konfliktu jego los był zdany przede wszystkim na lokalne społeczeństwo, które miało dosyć wewnętrznej wojny w prowincji, a prezydent Megawati Sukarnoputri była jedynie figurą przy podpisywaniu traktatu pokojowego w $2002 \mathrm{r}$. 
W wyżej omówionych okolicznościach bardzo ważnym czynnikiem była religia, która $\mathrm{w}$ czasach kolonialnych, a potem po odzyskaniu niepodległości, ukształtowała tożsamość społeczeństwa na Molukach. Odgrywała istotną rolę podczas holenderskiego faworyzowania chrześcijan a następnie $\mathrm{w}$ trakcie polityki transmigrasi, gdzie faktycznie dążono do równomiernego rozprzestrzenienia muzułmanów po całym archipelagu. Synkretyzm religijny, prawo adat oraz system pela przyczyniły się do utrzymania pokojowych relacji wśród rdzennej ludności różnego wyznania i pochodzenia etnicznego, szczególnie na wsiach. Można się nawet posunąć do stwierdzenia, że wspomniany synkretyzm religijny otworzył niejako drogę do dialogu międzywyznaniowego. Jednak napływ osób z zewnątrz, nierespektujących miejscowych reguł, walnie przyczynił się do zaostrzenia konfliktu między muzułmanami a chrześcijanami.

Powszechnie promowana tolerancja religijna w Indonezji jest pewną niekonsekwencją, co pokazało sprowadzenie życia duchowego do sześciu oficjalnie rozpoznawalnych religii. Okazało się, że idea ,jedność w różnorodności” została narzucona obywatelom, którzy nie chcieli się integrować na poziomie ogólnonarodowym. Mieszkańcy Moluków żyli spokojnie aż do momentu wymuszonego przyjmowania mieszkańców innych wysp, którzy zdecydowanie różnili się od nich pod względem kulturowym. Konflikt dobitnie pokazał klęskę polityki transmigrasi tak usilnie promowanej przez Suharto. Tłumione przez wiele lat niesnaski przyczyniły się do eskalacji walk, które spowodowały, że Moluki przez wiele lat były niedostępnym i zacofanym miejscem. Obecnie prowincja powoli odżywa, dzięki stosowaniu prawa zwyczajowego oraz wykorzystania synkretyzmu religijnego do pokojowej koegzystencji. Działające wcześniej tradycyjne źródła regulacji stosunków społecznych przyczyniły się do niemal wzorowej realizacji postanowień pokojowych. 


\section{Bibliografia}

Abuza, Z. 2007. Political Islam and Violence in Indonesia. New York: Asian Security Studies.

Ananta, A. (et. al.). 2015. Demography of Indonesia's Ethnicity. Singapore: ISEAS-Yusof Ishak Institute.

Aspinall, E., Jeffrey, R., Regan, A.J. 2007. Diminishing conflicts in Asia and the Pacific. Why some subside and others don't. New York: Routledge.

Andaya, L.Y. 1993. The World of Maluku: Eastern Indonesia in Early Modern Period. Honolulu: University of Hawaii Press.

Bartels, D. 1977. Guarding the Invisible Mountain: Intervillage Alliances, Religious Syncretism and Ethnic Identity among Ambonese Christians and Moslems in the Moluccas. Cornell University Press: New York.

Bertrand, J. 2004. Nationalism and Ethnic Conflict in Indonesia. Cambridge: Cambridge University Press.

Bowker, J. (ed.) 1997. The Oxford Dictionary of World Religions. Oxford: Oxford University Press.

Bonczol, Ł. 2012. Zrozumieć Indonezję. Nowy Ład generała Suharto. Warszawa: Dialog.

Braithwaite, J., Duhn, L. 2010. Maluku and North Maluku. w: J. Braithwaite, V. Braithwaite (et. al.), Anomie and Violence: non-truth and reconciliation in Indonesian peacebuilding. Canberra: ANU E Press.

Bräuchler, B. 2014. Modes of Interreligious Coexistence and Civility in Maluku. w: V. Gottowik, Dynamics of Religion in Southeast Asia: Magic and Modernity. Amsterdam: Amsterdam University Press.

Bräuchler, B. 2010. Integration and Exclusion, Islam adat in Central Moluccas. Indonesia and the Malay World, vol. 38, pp. 65-93.

Brown, G., Wilson, C., Hadi, S. 2005. Overcoming Violent Conflict. Peace and Development Analysis in Maluku and North Maluku. Jakarta: Crisis Prevention and Recovery Unit.

Bubandt, N. 2006. On the Genealogy of Sasi: Transformation and Imagined Tradition in Eastern Indonesia. w: P. Pedersen, T. Otto, Tradition and Agency: Tracing Cultural Continuity and Invention. Aarhaus: Aarhaus University Press.

Davidson, J.S., Henley, D. 2007. The Revival of Tradition in Indonesian Politics: the Deployment of adat from Colonialism to Indigenism. London: Routledge.

Duncan, C. 2013. Violence and Vengeance: Religious Conflict and Its Aftermath in Eastern Indonesia. New York: Cornell University Press.

Fuad ,M. 2002. Civil Soviety in Indonesia. The Potential and Limits of Muhammadiya. SOJOURN, vol. 17, pp. 133-163.

Goss, J. 2000. Understanding the Maluku Wars. Overview of sources of communal conflict and Prospects for Peace. Cekalele, nr 11, pp. 7-39.

Hasan, N. 2005. Between Transnational Interest and Domestic Politics: Understanding Middle Eastern Fatwas on Jihad in the Moluccas. Islamic Law and Society, vol. 12, pp. 73-92.

Higgins, N. 2009. Regulating the Use of Force in Wars of National Liberation: The Need for a New Regime. A Study of the South Moluccas and Aceh. Leiden: Brill.

Hoey, B.A. 2003. Nationalism in Indonesia: Building Imagined and International Communities through Transmigration. Ethnology 2003, vol. 42, pp. 109-126.

Forshee, J. 2006. Culture and Customs of Indonesia. Greenwood: Greenwood Publishing Group. 
Jeroen, A. 2010. How ordinary folk became involved in the Ambonese conflict Understanding private opportunities during communal violence. Bijdragen tot de Taal-, Land-en Volkenkunde, vol. 166, pp. 25-48.

Jeroen, A. 2007. Post-Conflict Ambon: Forced Migration and the Ethno-Territorial Effects of Customary Tenure. Development and Change, vol. 41, pp. 401-419.

Jeroen, A. 2010. Forced migration, adat and purified present in Ambon, Indonesia. Ethnology, vol. 41, pp. 227-238.

Laskowska, N. 2012. Indonezja. Warszawa: TRIO.

Leirissa, R. Z. 1995. Social Development in Ambon During the 19th century: Ambonese Burger. Cakalele, nr 6, pp. 1-11.

Lowry, C. S., Littlejohn, S. 2006. Dialogue and the discourse of peacebuilding in Maluku, Indonesia. Conflict Resolution Quarterly, vol. 23, pp. 409-426.

Martí, F. (et al.). 2005. Words and Worlds. World Languages Review. Trowbridge: Multilingual Matters.

Soebadio, H. 1978. Dynamics of Indonesia History. Amsterdam: North-Holland Publishing Company.

Ricklefs, M.C., 2001. A History of Modern Indonesia since c. 120o. Third Edition. Hampshire: Palgrave Macmillan.

Rudnyckyj, D. 2013. Spirits and Citizens: the Politics of Religious Differences in Indonesia. w: T. Reuter, A. Horstmann (ed.), Faith in the Future. Understanding the Revitalization of Religions and Cultural Transitions in Asia. Leiden: Brill.

Seo, M. 2013. State Management of Religion in Indonesia. New York: Routledge. Van Klinken, G. 2007. Communal Violence and Democratization in Indonesia. Small Town Wars. New York: Routledge.

Wilson, C. 2008. Ethno-religious violence in Indonesia: from soil to God. New York: Routledge.

\section{Źródła internetowe}

Bartels, D. 2003. The Evolution of God in the Spice Islands The Converging and Diverging of Protestant Christianity and Islam in the Colonial and Post-Colonial Periods, referat zaprezentowany na sympozjum "Christianity in Indonesia" we Frobenius Institute of the Johann Wolfgang Goethe University Frankfurt/Main 14 grudnia, 2003, @http://www.nunusaku.com/pdfs/ evolution.pdf, [14 maja 2015].

Bartels, D. 2000. Your God Is No Longer Mine: Muslim Christian Fratricide in the Central Moluccas (Indonesia) After a Half-Millenium of Tolerant Co-Existence and Ethnic Unity, @http://www.nunusaku.com/o3_publications/articles/ yourgod.html, [21 maja 2015].

Bartels, D. 1979. Politicians and Magicians Power, Adaptive Strategies, and Syncretism in the Central Moluccas, @http://www.nunusaku.com/pdfs/ politicians_magicans.pdf, [13 maja 2015].

Baza statystyczna Badan Pusat Statistik, @http://sp201o.bps.go.id/index.php/ site/tabel?tid=321\&wid=8100000000@http://sp2010.bps.go.id/index.php/si te/tabel?tid $=321 \&$ wid $=0$ [18 czerwca 2016].

Bhakti, I.N., Yanuarti, S., Nurhasim, M. 2009. Military Politics, Ethnicity and Conflict in Indonesia. CRISE. Center for Research on Inequality, Human 
Investigationes Linguisticae, vol. XXXV

Security and Ethnicity, @http://r4d.dfid.gov.uk/PDF/Outputs/Inequality/ wp62.pdf [26 czerwca 2015].

Porozumienie Malino II, @http://peacemaker.un.org/sites/peacemaker.un.org/ files/ID_020214_Moluccas\%20Agreement\%20in\%20Malino\%20(Malino\%20 II).pdf [30 maja 2015]. 